\title{
Growth in children on kidney replacement therapy: a review of data from patient registries
}

\author{
Marjolein Bonthuis $^{1}$ (D) Jérôme Harambat ${ }^{2} \cdot$ Kitty J. Jager $^{1} \cdot$ Enrico Vidal $^{3}$
}

Received: 1 April 2021 / Accepted: 27 April 2021 / Published online: 18 June 2021

(C) The Author(s) 2021

\begin{abstract}
Growth retardation is a major complication in children with chronic kidney disease (CKD) and on kidney replacement therapy (KRT). Conversely, better growth in childhood CKD is associated with an improvement in several hard morbidity-mortality endpoints. Data from pediatric international registries has demonstrated that improvements in the overall conservative management of CKD, the search for optimal dialysis, and advances in immunosuppression and kidney transplant techniques have led to a significant improvement of final height over time. Infancy still remains a critical period for adequate linear growth, and the loss of stature during the first years of life influences final height. Preliminary new original data from the European Society for Paediatric Nephrology/European Renal Association-European Dialysis and Transplant Association (ESPN/ERA-EDTA) Registry confirm an association between the final height and the height attained at 2 years in children on KRT.
\end{abstract}

Keywords Children · Growth $\cdot$ Final height $\cdot$ Chronic kidney disease $\cdot$ Kidney replacement therapy $\cdot$ Dialysis $\cdot$ Transplant

\section{Introduction}

Chronic kidney disease (CKD) has wide-ranging and longterm consequences for children and their families, including growth retardation, which is a marker of disease severity. Growth retardation may occur at any stage of CKD and is related to multiple modifiable and non-modifiable risk factors [1]. The latter include age at onset of CKD, abnormal birth history, kidney disease etiology, genetic factors (i.e., parental height), and use of required medications (i.e., steroids for immune-mediated diseases or after kidney transplantation) [2]. Primary pathogenic mechanisms can involve prenatal/ perinatal factors, nutrition and caloric intake, mineral and

Marjolein Bonthuis

m.bonthuis@amsterdamumc.nl

1 ESPN/ERA-EDTA Registry, Department of Medical Informatics, Amsterdam Public Health Research Institute, Amsterdam UMC, University of Amsterdam, Meibergdreef 9, J1B-108.1, P.O. Box 22700, 1100 DE Amsterdam, The Netherlands

2 Department of Pediatrics, Bordeaux University Hospital, Bordeaux Population Health Research Center UMR 1219, University of Bordeaux, Bordeaux, France

3 Division of Pediatrics, Department of Medicine, University of Udine, Udine, Italy bone metabolism disorders, hormonal influences from the pituitary gland, and other metabolic abnormalities (collectively termed as uremic milieu), including metabolic acidosis, anemia, and inflammation.

Clinical and experimental evidence demonstrates that perturbations in the growth hormone (GH)-insulin-like growth factor-1 (IGF-1) axis are responsible for many important complications seen in CKD, such as growth retardation and protein energy wasting, as well as disease progression $[1,3,4]$. These alterations include changes in the 24-h levels of spontaneous GH release, reduced GH receptor density in target organs, and disturbed cascade of intracellular signaling events (post-receptor defect). This results in a functional IGF-1 deficiency, in which free bioactive levels are further reduced by an increased binding capacity due to excess of IGF-binding proteins. Growth hormone insensitivity in CKD lays the basis for recombinant human growth hormone therapy (rhGH), an effective and well-tolerated intervention to improve growth.

Adequate physical growth is a paramount outcome in children with CKD. Better growth in childhood CKD is associated with an improvement in several hard clinical endpoints [5-9]. Moreover, adequate stature during pediatric CKD influences patient and parental perspectives [10,11], and satisfaction with adult life [12].

Given the overall impact of growth on health-related quality of life (HRQoL), evaluation, prevention, and management 
of growth failure are essential in children with CKD. Trends in physical growth are commonly evaluated in registry-based research and might indicate a change in the epidemiology of childhood CKD.

In this review, we aim to give an overview of the statural growth in children receiving chronic kidney replacement therapy (KRT), integrating data from international registries. Moreover, prompted by a suggestion from Professor Lesley Rees during a recent scientific meeting, we used data from the European Registry for Children on KRT (European Society for Paediatric Nephrology/European Renal AssociationEuropean Dialysis and Transplant Association (ESPN/ERAEDTA) Registry) to evaluate the hypothesis that height attained during infancy in stage 5 chronic kidney disease (CKD 5) patients is a predictor of final height.

\section{Association of growth retardation with outcomes}

Growth failure after pediatric KRT has been associated with poor social and health outcomes. In pre-dialysis populations, HRQoL was lower among children with short stature [11, 13], and height gains and rhGH use were associated with improved parent-reported HRQoL [11]. In a recent analysis from the Kids with CKD study, among 375 children from Australia and New Zealand with CKD, on dialysis and after kidney transplantation (KT), quality of life scores were significantly lower among dialysis patients, and short stature was associated with poorer quality of life [14]. Children with short stature more often have emotional and behavioral problems, including anxiety, low self-esteem, social immaturity, learning disabilities, and poor academic achievement $[15,16]$. One-third of adult patients with childhood onset CKD 5 were dissatisfied with their body height [17], and a Dutch cohort study found that patients starting KRT $<15$ years of age who attained a short adult height were less likely to have children after 30 years on KRT [18]. Furthermore, short stature has been associated with lower levels of employment and lower marital status [12]. However, a more recent study on adult social and professional outcomes after pediatric KT did not find such associations, and the authors concluded that height seemed to be sufficiently improved and is no longer a major determinant in social and professional outcomes after pediatric CKD 5 [19].

Short stature could also affect kidney graft function. In the CKiD cohort, patients with a short stature prior to transplantation had a $40 \%$ shorter time to reaching an eGFR $<45 \mathrm{ml} /$ $\min / 1.73 \mathrm{~m}^{2}$ after KT compared to children with a normal stature, although this association was partly explained by socio-economic status, disease severity, and mid-parental height [20].
Finally, short stature in pediatric CKD 5 has also been associated with increased hospitalization [7] and mortality $[7,9,21]$, mainly due to a higher risk of infectious complications. Although not causally associated, the elevated mortality risk in CKD 5 patients with short stature may in part reflect poor nutritional status and severity of illness. Still, the associations of growth failure with poor patient outcomes indicate the importance of obtaining a normal adult height for the patients' daily functioning. Table 1 summarizes the associations of height in children on KRT and various outcome measures reported by several international pediatric KRT registries.

\section{Improvement in growth after KRT}

By the 1970s, the availability of KRT allowed many children with CKD 5 to survive into adulthood. Other clinical outcomes than patient survival then became critical, and special focus was put on growth in children with CKD in the following decades. Franke et al. have reported the gains made in growth and maturation in pediatric CKD 5 patients, particularly in Germany [23]. In the mid-1980s, the mean height standard deviation score (SDS) of 732 European children on KRT included in the EDTA registry was $<-3$. Mean height SDS markedly improved over time to -1.80 in 384 German children receiving KRT in the 1998-2009 era [23]. The final height also improved significantly over the past decades $[6$, 24]. In the USA, final height SDS for transplanted patients having reached 19 years $(n=2569)$ improved from -1.93 in $1987-1991$ to -0.89 in the 2007-2013 period [24]. Similarly, final height SDS increased from -2.06 SDS in European children on KRT who reached adulthood in 1990-1995 to -1.33 SDS in those reaching adulthood in 2006-2011 [6]. However, the ESPN/ERA-EDTA Registry showed no secular trends in growth post transplantation in European children between 1990 and 2012 according to the period of KT, suggesting that the improvement of final height over time is most likely explained by better pre-CKD 5 care [25].

\section{Dialysis}

In pediatric patients, dialysis should be considered as a transition period before receiving a $\mathrm{KT}$ and should aim at attaining adequate body weights for receiving a KT. In CKD patients, growth failure is an indication for dialysis initiation, and good growth and development during dialysis are the principal indices of dialysis adequacy. "Adequate dialysis" usually refers to a minimum dose below which a clinically unacceptable rate of negative outcomes occurs, and it is defined by a fixed threshold or a number. Given the strong association between growth, clinical outcomes, and quality of life in children 
Table 1 Associations between height and different outcome measures: results from international registries

\begin{tabular}{|c|c|c|}
\hline Outcome measure & Registry database & Result \\
\hline \multirow[t]{2}{*}{$\begin{array}{l}\text { Morbidity } \\
\text { (hospitalization } \\
\text { rate) }\end{array}$} & USRDS [5] & $\begin{array}{l}\text { Increased risk of hospitalization in case of growth failure: } 1.8 \text { hospitalizations/patient year (py) in } \\
\text { severe growth failure, } 1.74 \text { hospitalizations/py in moderate growth failure, and } 1.2 \\
\text { hospitalizations/py for normal growth subjects over } 5 \text { years of follow-up. After adjustment, } \\
\text { patients with severe (HR: } 1.12,95 \% \mathrm{CI}: 1.03-1.22 \text { ) and moderate (HR: } 1.26,95 \% \text { CI: } \\
\text { 1.17-1.36) growth failure had higher hospitalization rates than those with normal growth }\end{array}$ \\
\hline & NAPRTCS [7] & $\begin{array}{l}\text { Patients with short stature (height SDS }<-2.5 \text { SDS) had significantly more hospital days per } \\
\text { month than patients with height } \geq-2.5 \text { SDS (median } 0.73 \text { compared with } 0.44, p<0.001 \text { ) }\end{array}$ \\
\hline \multirow[t]{2}{*}{ Mortality } & USRDS [9] & $\begin{array}{l}\text { Risk of death was higher in children with short }\left(<3^{\text {rd }} \text { percentile) (HR: } 1.49,95 \% \text { CI: } 1.33-1.66\right) \\
\text { and tall }\left(>97^{\text {th }} \text { percentile) (HR: } 1.32,95 \% \text { CI: } 1.03-1.69\right) \text { stature at KRT initiation. }\end{array}$ \\
\hline & NAPRTCS [7] & $\begin{array}{l}\text { Children initiating dialysis with height SDS }<-2.5 \text { were more likely to die than patients with } \\
\text { height in the normal range (HR: } 2.07,95 \% \text { CI: } 1.53-2.79 \text { ) }\end{array}$ \\
\hline \multirow[t]{3}{*}{ Final height } & NAPRTCS [22] & $\begin{array}{l}\text { Incidence of retarded final height SDS }(<-1.88) \text { was increased in patients with low height SDS at } \\
\text { transplantation (OR: } 0.39, p=0.001)\end{array}$ \\
\hline & ESPN/ERA-EDTA [6] & $\begin{array}{l}\text { Height SDS at start of KRT was positively associated with final height SDS. Adjusted final height } \\
\text { SDS was } 0.37 \text { (95\% CI: } 0.32-0.41 \text { ) higher per } 1 \text { SDS increase in height SDS at KRT }\end{array}$ \\
\hline & $\begin{array}{l}\text { ESPN/ERA-EDTA } \\
\quad \text { (Unpublished data, 2021) }\end{array}$ & $\begin{array}{l}\text { Height SDS at } 2 \text { years seemed positively associated with final height SDS }(\beta=0.17, p=0.05 \text { ) } \\
\text { (Fig. 2) }\end{array}$ \\
\hline
\end{tabular}

receiving KRT, "adequate growth" becomes a marker of "optimal dialysis" in this setting.

In the 2011 annual dialysis report from the NAPRTCS registry [26], the 5022 patients had on average a height SDS of -1.60 at dialysis initiation. Height deficits were worse for males, younger patients, and those treated with hemodialysis (HD) as compared with peritoneal dialysis (PD). Patients were also stratified according to a baseline height deficit: height SDS $<$ or $>$ than the third percentile of the normal population. Children with a height SDS $>3^{\text {rd }}$ percentile at baseline experienced a decrease in height SDS during the dialysis course, whereas the height SDS of children with a height $\mathrm{SDS}<3^{\text {rd }}$ percentile at baseline improved slightly from -3.21 SDS to -2.90 SDS by 24 months. In all age categories, children treated with HD experienced a worse median change from baseline during the dialysis course, as compared with PD.

\section{Residual kidney function}

Residual kidney function (RKF) exerts a significant influence on growth in children on dialysis and is a better predictor of longitudinal growth than dialytic clearance. In 24 patients treated with PD for a minimum of 1 year [27], the mean height SDS changed from -1.58 at baseline to -1.78 after 1 year of treatment. Catch-up growth was observed in 9 patients (37\%), 7 of whom had RKF. In contrast, only 5 of 15 patients (33\%) with a negative delta height SDS had RKF. Similarly, an analysis of 12-month follow-up data in 214 pre- and early-pubertal patients in the International Pediatric Peritoneal Dialysis Network (IPPN) database showed that preserved residual diuresis was significantly associated with the odds of increasing height SDS in children treated with PD (odds ratio: $3.25 ; 95 \%$ confidence interval: 1.66-6.31) [28].

\section{Peritoneal dialysis}

There are few papers describing growth outcomes in infants on chronic PD, and the results from these studies are controversial. In the cohort studied by Ledermann et al. [29], mean height SDS at the start of PD was -1.8 , and it increased to -1.1 at 1 year and to -0.8 at 2 years. The majority of the 20 children in this case series were affected by CAKUT and had preserved RKF. None of the infants received rhGH therapy, while 18 were given enteral feeding via a nasogastric tube or percutaneous gastrostomy. In a sample of 84 infants who started PD at $<1$ year of age, the Italian Registry of Chronic Dialysis showed that mean height SDS was -1.65 at the start of chronic PD, -1.82 after 12 months, and -1.53 after 24 months [30]. The longer follow-up in this study allowed demonstration of a catch-up growth in half of the treated infants, and SDS values at 2 years of follow-up were similar to those at PD initiation. Infants with catch-up growth were not different from those without, with regard to several biochemical parameters, RKF, distribution of comorbidities, and proportion of children on rhGH treatment. Interestingly, a positive relationship was found between height SDS and both fill volume and treatment duration after 1 year of PD. Moreover, children with better growth rates suffered from a significantly lower number of peritonitis episodes.

Among 153 children from the IPPN Registry who initiated PD during infancy, the use of biocompatible PD fluids low in toxic glucose degradation products was consistently 
associated with better body growth [31]. The association prevailed even after correction for nutritional status and region, and was quantitatively stronger than the effect of gastrostomy feeding.

These findings suggest that the management of growth failure in children on PD can be optimized using a maximum dialytic and nutritional approach and by examining all suitable strategies for preserving diuresis, reducing peritoneal membrane inflammation, and preventing peritonitis. Dialysis prescription should not be based on the worsening of biochemical parameters but instead should reflect a timely tailoring to body size, RKF, and metabolic needs.

\section{Hemodialysis}

In children on chronic $\mathrm{HD}$, despite reaching an adequate dialysis dose based on urea kinetic modeling, many children do not show improvement of appetite, weight gain, or statural growth. With conventional HD, significant dietary and fluid restrictions are needed to prevent interdialytic weight gain during the "off dialysis" days. However, implementing these restrictions becomes challenging, especially in the pediatric age group. Clinical signs of underdialysis indicate that the prescription should be optimized. HD intensification relies on modification of factors such as duration, frequency, time, and modality (HD versus hemodiafiltration (HDF)). In a pilot study by Fischbach et al. [32], five oligoanuric dialysis patients were converted from standard HDF ( $4 \mathrm{~h}$, three times/ week) to daily online HDF ( $3 \mathrm{~h}$, six times/week). After 6 months, the only prepubertal child included showed a significant catch-up growth, resulting in a height SDS gain of 1.5 over 24 months. De Camargo et al. performed an observational study on 24 children with CKD 5 undergoing daily HD [33]. The authors found that the intensified prescription favored a 0.5 SDS height gain in one-third of patients without rhGH treatment as compared with $8 \%$ in a control group of 26 children on a concurrent conventional HD regimen. In a large multi-center observational study comparing outcomes of conventional HD versus post-dilution online HDF in children [34], a significant increase in height SDS over 1 year of treatment was found in patients on convective therapy, whereas height SDS remained stable in conventional HD. Convective therapies might achieve higher clearance of middle molecules, including IGF-1 binding proteins that contribute to functional IGF deficiency and relative rhGH insensitivity.

\section{Kidney transplantation}

Growth after KT is mainly affected by the degree of pretransplantation height deficit, age at KT, graft function, and steroid exposure.

\section{Pre-KRT growth}

Growth determinants during the pre-KRT period may include age at diagnosis of $\mathrm{CKD}$, nutritional intake, primary kidney disease, tubular impairment, CKD-mineral bone disorder (CKD-MBD), hormonal disorders, and pre-transplantation use of rhGH and steroids. Two periods are at a particular risk of impaired growth velocity: infancy and puberty. Height velocity generally decreases once GFR is below $25 \mathrm{ml} / \mathrm{min} / 1.73$ $\mathrm{m}^{2}$ [35]. However, there is evidence that growth impairment already starts earlier. Indeed, in a CKD analysis of the NAPRTCS [36] including 1901 patients with CKD stage 2 (GFR of $50-75 \mathrm{ml} / \mathrm{min} / 1.73 \mathrm{~m}^{2}$ ), 22\% had height SDS below the third percentile $(\leq-1.88)$, and in 2477 children with CKD stage 3 (GFR of $25-50 \mathrm{ml} / \mathrm{min} / 1.73 \mathrm{~m}^{2}$ ), $37 \%$ had a height $\mathrm{SDS} \leq-1.88$. Pre-KT growth impairment may be reduced by adequate conservative treatment of $\mathrm{CKD}$, including aggressive nutritional support during infancy and early childhood [37] and treatment with rhGH when indicated [4]. This has resulted in a significant improvement of pre-KT growth. Data from the NAPRTCS has shown a remarkable improvement in height SDS at the time of first KT, which increased from a mean of -2.4 in 1987 to -1.4 SDS in the 2008 cohort [38].

\section{Age at transplantation}

In an ESPN/ERA-EDTA report [25], only infants and preschool age children (2 to 5 years) exhibited catch-up growth post-transplantation (Fig. 1). However catch-up growth occurred mainly during the first 3 years post-transplantation, and no further improvement was observed thereafter; preschool age children who had the largest deficit at the time of KT ( $<-2$ SDS) exhibited the best growth improvement of 0.6 to 0.8 SDS. Conversely, school age children (6 to 12 years) and adolescents demonstrated either a limited improvement in height SDS or even no catch-up growth after KT (Fig. 1). Similar growth patterns have been reported by the NAPRTCS [38]. The prepubertal growth deceleration that occurs in the normal population is prolonged after KT, and puberty and bone age are usually delayed $[39,40]$. This means that growth continues for longer than normal, but the height gain is rarely as much as expected due to loss of height potential $[39,41]$. However, some authors have reported that normal pubertal development and significant catch-up growth can occur post-KT even in children of pubertal age [42, 43].

\section{Kidney graft function}

The effect of a reduced GFR on growth has been known for a long time [44]. A report from the NAPRTCS assessed final adult height in recipients transplanted before 11 (girls) or 12 (boys) years, showing that a decreased GFR was an independent predictor of reduced final height [22]. Guest et al. 


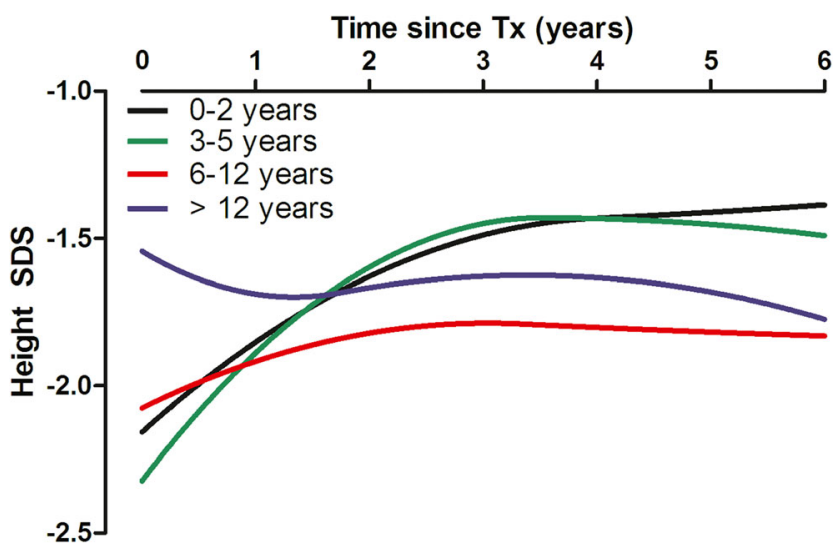

Fig. 1 Unadjusted post-transplant growth patterns stratified by age at kidney transplantation. (Reproduced with minor revision from [25], used with permission)

reported that prepubertal children with a serum creatinine above $120 \mu \mathrm{mol} / \mathrm{L}$ did not exhibit catch-up growth in the first year post-KT [45]. Nissel et al. showed that prepubertal catchup growth and total pubertal height gain correlated positively with GFR [39]. Data from the NAPRTCS found that graft function at 1 and 12 months was associated with growth after KT; those with a GFR $>90 \mathrm{ml} / \mathrm{min} / 1.73 \mathrm{~m}^{2}$ showed improved height SDS over time [38]. An analysis by eGFR group 12 months after transplantation showed similar results. More recent studies confirmed that graft function is a major determinant of growth after KT $[25,46]$.

\section{Steroid therapy}

Since its introduction more than 60 years ago, it has become clear that daily and prolonged steroid therapy leads to growth impairment [47]. Steroid therapy inhibits growth through interferences with the hypothalamus-pituitary/growth hormone/ insulin-like growth factor axis and by its direct effect on bone formation. It has also been suggested recently that steroids may decrease longitudinal bone growth in pediatric KT recipients by stimulating the FGF23/FGFR3 signaling pathway [48]. Pharmacokinetic studies of methylprednisolone in pediatric liver and kidney transplant recipients have demonstrated that area under serum concentration-time (AUC) rather than dose was predictive for growth retardation $[49,50]$. However, this correlation between AUC and growth was not unanimously found in transplanted children treated with prednisone or prednisolone [51]. Observational and registry data showed that steroid exposure is associated with post-transplant height SDS $[25,52]$. There have been studies in the 1990s suggesting an improvement in growth with daily low or alternate-day steroid therapy $[53,54]$. Steroid withdrawal/avoidance protocols in pediatric KT have been associated with a significant improvement in height SDS in randomized controlled trials [55-59]. Prepubertal recipients appeared to have the greatest benefit which seems to be only very limited in pubertal children (Table 2).

\section{Donor type}

Pape et al. identified 51 boys who received a KT ( 30 deceased donors and 21 living related donors) before the rhGH era and were followed for at least 5 years [60]. Children who received a living donor kidney had a significantly greater height SDS and growth velocity in the first 5 years post-transplantation than those who received a graft from a deceased donor. Interestingly, this difference remained significant after adjustment for potential confounders, including graft function. In the NAPRTCS, living donor kidney recipients had a reduced height deficit compared to that of deceased donor kidney recipients, and this difference persisted after transplantation, but the mean adjusted difference was less than 0.3 SDS at 5 years post-KT [38]. In the ESPN/ERA-EDTA Registry, children who received a deceased donor kidney were shorter by 0.15 SDS at KT and tended to show a lower catch-up growth posttransplant than those transplanted with a living donor $(+0.35$ SDS deceased vs. + 0.39 SDS living) [25].

\section{Preemptive kidney transplantation}

As dialysis is associated with decreased growth velocity, preemptive KT might optimize growth outcome. Some studies suggested better height SDS in the first years posttransplantation in those children who received a preemptive KT compared to those with dialysis prior to KT [38, 43, 61]. However, this finding was not confirmed by others after adjustment for potential confounders $[46,52]$.

\section{Other factors}

A previous NAPRTCS report suggests that race/ethnicity may also have an impact on growth following transplantation [62]. The change in height SDS was negative in African-American and Hispanic recipients but positive in Caucasians. However, ethnicity did not significantly influence growth in multivariable analysis.

Birth parameters are important determinants of posttransplant growth. Children born small for gestational age (SGA) have significantly poorer growth outcome after KT compared with non-SGA patients, and their growth is more likely to be affected by other factors such as use of rhGH in the pre-transplant period, preemptive KT, and graft function [63].

Finally, several clinical factors like primary kidney disease (congenital CKD, syndromic disease), anemia, high blood pressure, metabolic acidosis, or vitamin D deficiency have variable associations with height SDS and growth post-KT $[25,46,52,64]$. 
Table 2 Summary of RCTs of steroid withdrawal/avoidance and the effects on growth

\begin{tabular}{|c|c|c|c|c|c|c|c|c|c|}
\hline \multirow[t]{2}{*}{ Author } & \multirow[t]{2}{*}{ Year } & \multirow{2}{*}{$\begin{array}{l}\text { Follow-up } \\
\text { (months) }\end{array}$} & \multirow[t]{2}{*}{ Intervention } & \multirow{2}{*}{$\begin{array}{l}\text { Steroid } \\
\text { withdrawal/ } \\
\text { avoidance } \\
\mathrm{N}\end{array}$} & \multicolumn{3}{|c|}{ Change in height SDS } & \multirow[t]{2}{*}{ Controls } & \multirow{2}{*}{$\begin{array}{l}\text { Change in } \\
\text { height SD }\end{array}$} \\
\hline & & & & & Overall & Prepubertal & Pubertal & & \\
\hline $\begin{array}{c}\text { Hocker } \\
{[55]}\end{array}$ & 2010 & 24 & Late withdrawal & 23 & 0.60 & $0.70(n=13)$ & $\begin{array}{l}0.40 \\
\quad(n=7)\end{array}$ & 19 & -0.20 \\
\hline $\begin{array}{c}\text { Benfield } \\
{[56]}\end{array}$ & 2010 & 30 & Late withdrawal & 73 & 0.16 & & & 59 & -0.04 \\
\hline $\begin{array}{r}\text { Sarwal } \\
{[57]}\end{array}$ & 2012 & 36 & Avoidance & 60 & -0.92 & $\begin{array}{l}-0.43 \\
\quad(n=11<5 \text { years })\end{array}$ & & 70 & -0.96 \\
\hline $\begin{array}{c}\text { Mericq } \\
{[58]}\end{array}$ & 2013 & 12 & Early withdrawal & 14 & 1.20 & $1.30(n=12)$ & & 16 & 0.60 \\
\hline $\begin{array}{l}\text { Webb } \\
{[59]}\end{array}$ & 2015 & 24 & Early withdrawal & 98 & 0.57 & $0.69(n=48)$ & $\begin{array}{l}-0.04 \\
\quad(n=50)\end{array}$ & 98 & 0.33 \\
\hline
\end{tabular}

\section{Final height}

Despite adequate metabolic and nutritional control, intensified dialysis regimens, and successful KT, reduced final height (below the third percentile for age and sex) is present in approximately $40 \%$ of pediatric CKD 5 patients $[6,23]$. The median final height ranges from 145 to $162 \mathrm{~cm}$ in females and from 156 to $174 \mathrm{~cm}$ in males [6, 24, 39, 65-67]. In Europe, the median (IQR) final height after childhood KRT was $-1.65(-2.64 ;-0.78)$ SDS and did not significantly differ between boys and girls [6], whereas the NAPRTCS registry reported a median final height of -1.23 SDS [24], a difference most likely caused by the use of different reference charts [68].

Important determinants of final height are older age at start of KRT and KT, cumulative time with a functioning graft, and greater height SDS at KRT initiation and at KT [6, 39, 65, 69] (Table 1). Additionally, post-transplant catch-up growth is restricted to the youngest patients ( $<6$ years at KT) [25, 69], and there was no improvement in post-KT height SDS in the past 25 years in Europe, suggesting that better growth management in the pre-CKD 5 period is mainly responsible for the improvement in final height. The pre-existing height deficit thus seems to be one of the most important factors for the final height of pediatric CKD 5 patients.

In line with this, we hypothesized that the height of young children with CKD 5 is already predictive for their final height. To study the association between height SDS at the age of 2 years and final height SDS, we used data from the ESPN/ERA-EDTA Registry. Data was available for 101 patients from 13 European countries (60\% male, $41 \%$ congenital anomalies of the kidney and urinary tract, median age at KRT (IQR): $1.7 ; 0.8-2.5$ years). Height SDS was expressed according to national or European growth charts [68]. Linear regression analysis was used, and we adjusted for potential confounders. Indeed, after adjusting for age and period at KRT initiation, sex, and cause of kidney failure, there was a trend toward an association between height SDS at the age of 2 years and final height $\operatorname{SDS}(\beta=0.17, p=0.05)$ (Fig. 2) (Unpublished data ESPN/ERA-EDTA Registry, 2021). However, further research on a larger number of subjects (including those not (yet) on KRT) should reveal whether height at young age is truly predictive of final height in pediatric CKD 5.

The current final height of CKD 5 patients remains suboptimal, but strategies such as steroid avoidance/withdrawal immunosuppressive regimens in KT recipients $[65,66]$ and more regular use of rhGH [70, 71] may improve final height, possibly even when started during puberty [67]. The expected increase in final height after being treated with rhGH for a period of 2-5 years approximates $7 \mathrm{~cm}$ [4]. However, unfortunately rhGH prescription seems to be limited and mostly determined by physician and patient attitudes toward rhGH therapy rather than by financial hurdles [72].

\section{Role of nutrition}

Inadequate nutrition is a common cause of growth failure in children with CKD. Reduced appetite, gastroesophageal reflux, and vomiting are important factors contributing to poor nutritional intake [73]. Poor appetite has several potential causes and may result from reduced taste sensation, which worsens when CKD progresses [74], restrictive diets, medication use, protein losing states, polydipsia [75], and chronic inflammation [76].

Growth in early childhood is crucial for final height potential as one-third of postnatal statural growth occurs during the first 2 years of life. In infants and young children, poor nutrition is the most important factor contributing to growth impairment [77]. 
Fig. 2 Final height standard deviation scores (SDS) by height SDS at the age of 2 years among 101 patients on kidney replacement therapy (KRT) from the ESPN/ERA-EDTA Registry. The solid line depicts the linear regression analysis adjusted for age and period of KRT, sex, and cause of kidney failure

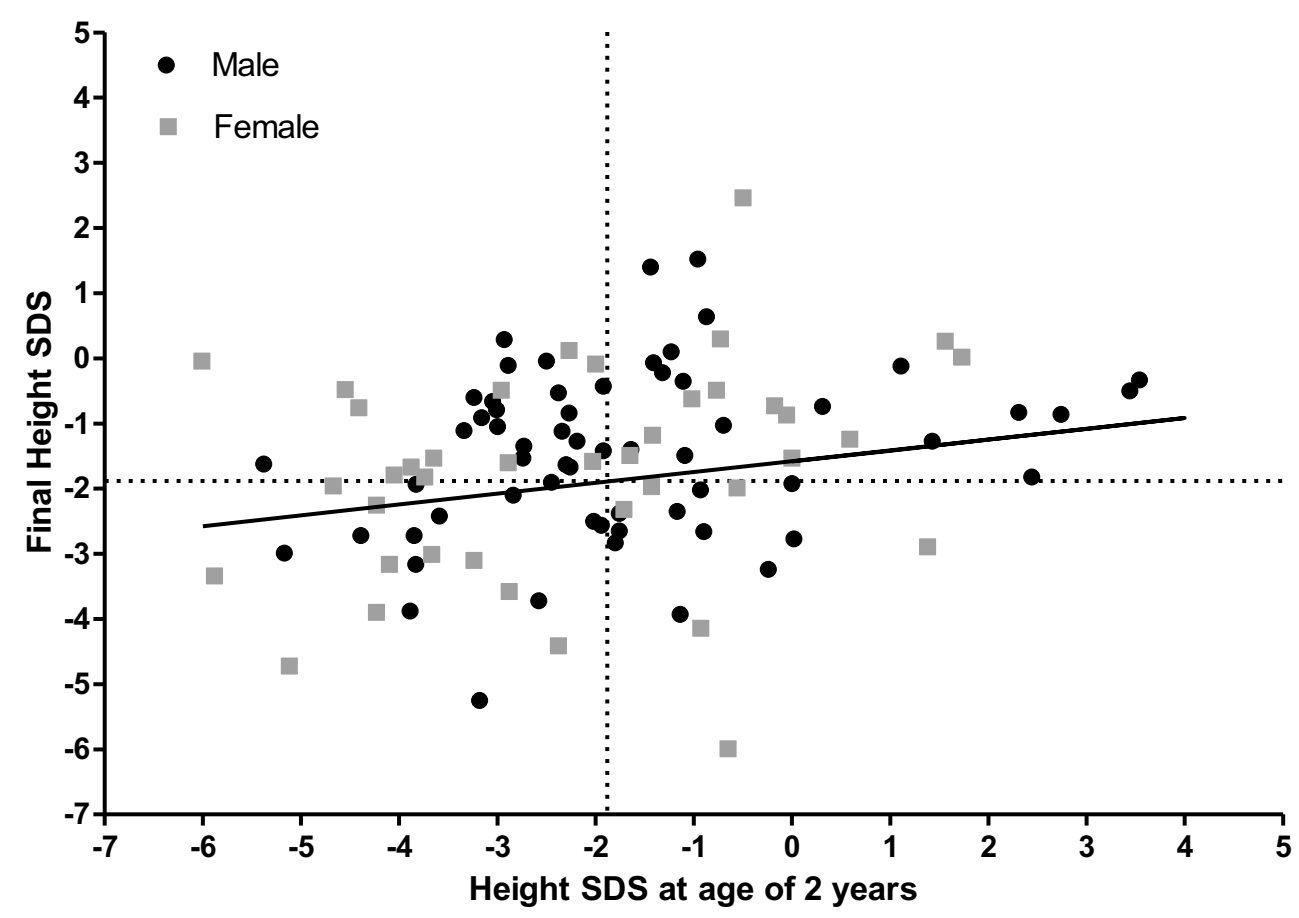

On the other hand, tube feeding is effective in improving BMI SDS [31, 79]. Paralleling the global obesity epidemic, overweight and obesity are also emerging problems in the pediatric CKD population [80-82]. According to the ESPN/ ERA-EDTA Registry, $20.8 \%$ of children $<16$ years on KRT were overweight, and $12.5 \%$ were obese [81]. In patients from the CKiD cohort, the reported median energy and protein intake among children with CKD was high, and at least half of the children consumed more energy and protein than recommended [83, 84].

Energy requirements and enteral feeding regimens should be adjusted in order to promote optimal growth and to prevent obesity. Surprisingly, both the IPPN Registry and the ESPN/ ERA-EDTA Registry found an association between short stature and obesity. These findings may reflect previous attempts to correct growth failure by energy-dense nutrition, in fact leading to overweight and obesity with very limited effect on height gain.

Nevertheless, optimal nutrition is important during all phases of growth in pediatric CKD, and successful nutritional management requires involvement of a pediatric renal dietician $[85,86]$.

\section{rhGH treatment}

Despite supportive measures aimed at correcting complications of CKD and optimization of KRT, some children with $\mathrm{CKD}$ or KT recipients cannot approach normal height without rhGH therapy [2]. The GH insensitivity in CKD can be overcome by the administration of supraphysiological doses of 
rhGH, which results in increased circulating levels of free IGF-1 and promotes longitudinal growth.

A Cochrane systematic review based on 16 randomized controlled studies (enrolling 809 children) demonstrated that 12 months of $28 \mathrm{IU} / \mathrm{m}^{2} /$ week rhGH in children with all clinical settings of CKD (conservative treatment, on dialysis, or after KT) resulted in a $3.88 \mathrm{~cm}$ increase in height velocity above that of untreated patients [87]. The frequency of reported side effects of rhGH was generally similar to that of the control group. Efficacy of rhGH therapy was further confirmed by observational data from the NAPRTCS registry [88]. A total of 787 children with CKD previously rhGH naïve who received rhGH for 1-4 years were paired with 787 control patients. Treatment with rhGH resulted in a significantly greater height velocity SDS, with no significant impact on the BMI or kidney function.

Recently, the ESPN CKD-MBD, Dialysis and Transplantation Working Groups published detailed clinical practice recommendations for the use of rhGH in children with CKD, on dialysis and after KT [4]. According to these recommendations, all children with stage $3-5 \mathrm{D}$ CKD, who have a well-defined growth failure despite correction of any amenable complications of CKD, should be candidates for rhGH therapy, provided they still have a growth potential. The same indication is provided for KT recipients who have not experienced any spontaneous catch-up growth 1 year after transplantation and a steroid-free immunosuppressive regimen is not feasible.

Despite supporting evidence, there are still many obstacles to rhGH therapy in children with CKD 5. Short stature might be perceived as a cosmetic issue only, and it is easy to ignore. This "lack of urgency" may result in a delayed prescription of rhGH therapy, thus reducing treatment efficacy [89]. Treatment costs and reimbursement mechanisms might also represent a barrier to care, but an ESPN/ERA-EDTA Registry study found patient and clinician attitudes toward rhGH therapy a bigger issue than costs [72]. Earlier initiation of rhGH in a small child could be more cost-effective, as it might also improve the patient body weight, thus allowing early KT and reducing the time on long-term dialysis.

Infants with CKD from their first months of life often have difficulty maintaining adequate nutrition, which contributes to the high prevalence of short stature in this population. The IPPN Registry analyzed data from 153 children in 18 countries who commenced chronic PD at $<24$ months of age [31]. In multivariate analysis, the administration of rhGH for at least 6 months was independently associated with improved length, even after adjusting for regional factors. Clinical experience supports the use of rhGH also in infants with CKD. The ESPN clinical practice guidelines recommend that rhGH therapy should be considered for infants older than 6 months of age with CKD 3-5D who have a poor growth despite provision of adequate nutrition [4].

\section{Key summary points}

i) Despite treatment advances in pediatric nephrology care growth retardation remains a major problem in patients treated for childhood CKD 5.

ii) Most improvements are observed in the pre-CKD 5 period, but optimization of dialysis care, steroid avoidance/ withdrawal regimens post-transplantation, and adequate use of rhGH treatment might be helpful to further decrease the burden of growth failure in children on KRT.

iii) According to our preliminary ESPN/ERA-EDTA Registry analysis, appropriate growth management during infancy is particularly critical, since patient final height seems associated with height attained at 2 years of age.

Multiple choice questions (answers are given after the reference list)

1. Which statement about growth in pediatric KRT patients is correct?

a) Improvements in height are mainly obtained during the pre-CKD 5 period

b) rhGH should not be initiated during infancy

c) Enteral feeding is only advised in dialysis patients

d) Height is not associated with increased hospitalization rates

2. Which factors are associated with better growth in pediatric patients treated with dialysis?
a) Biocompatible PD fluids
b) Hemodiafiltration
c) Residual kidney function
d) All of the above

3. Which patient group showed the poorest catch-up growth after kidney transplantation?
a) Infants
b) Pre-school children (2-5 years)
c) 6-12-year-old patients
d) Adolescents

4. How many pediatric KRT patients roughly grow up as stunted adults (i.e., have a reduced final height)?
a) $30 \%$
b) $40 \%$
c) $50 \%$
d) $60 \%$ 
5. According to the recent ESPN clinical practice guidelines on rhGH which patients would be eligible for $\mathrm{rhGH}$ therapy?

a) Dialysis patients with growth failure

b) All children with CKD, on dialysis and after kidney transplantation with growth failure

c) CKD and dialysis patients with growth failure

d) All children with CKD stage 3-5D with growth failure once other potentially treatable risk factors for growth failure are adequately addressed, and there is growth potential, as well as KT patients without spontaneous catch-up growth 1-year post-KT and if steroid-free immunosuppression is not possible.

Acknowledgements We would like to thank the patients, their parents, and the staff of all the dialysis and transplant units who have contributed data via their national registries and contact persons. We also would like to thank R Topaloglu, J Oh, Z Massy, T Jahnukainen, and MD Sinha for being members of the ESPN/ERA-EDTA Registry Committee, D Shtiza, F Engler, J Kerschbaum, G Mayer, R Kramar, S Baiko, O RaikevicLiachovskaya, A Dudarevich, I Sheuchuk, D Pokrajac, K van Hoeck and the Centre contributors to the Belgian Registry Committee, D Roussinov, E Maurer, GF Laube, CE Kuehni, P Parvex, S Tschumi, L Mader, and the Swiss Paediatric Renal Registry, A Elia, T Seeman, K Vondrak, K Krupka, B Höcker, L Pape, B Tönshoff, K Rascher, E Nüsken, L Weber, G von Gersdorff, J Dötsch, F Schaefer, K Hommel, Ü Toots, A Alonso Melgar and the Spanish Paediatric Registry, J Helve, P Finne, P-H Groop, C Couchoud, M Lassalle, E Berard, T Davitaia, G Moustakas, A Kapogiannis, A Mitsioni, N Printza, D Milosevic, M Ban, J Slavicek, D Arapovic, S Abdovic, G Reusz, Cs Berecki, A Szabó, T Szabó, A Barczi, O Lakatos, A Vègh, A Awan, T Raftery, C Sweeney, N Dolan, Riordan, M Stack, M Waldron, R Palsson, V Edvardsson, B Gianoglio, I Guzzo, E La Porta, F Paglialonga, C Pecoraro, E Verrina, A Jankauskiene, S Rudiatis, A Popova, V Kuzema, H Černevskis, S Gatcan, O Berbeca, N Zaikova, N Revenco, E Sahpazova, N Abazi, S Pavićević, V Said-Conti, L Heuveling, S Vogelaar, and MH Hemmelder on behalf of the Nefrovisie foundation, JW Groothoff and all centers participating in the RichQ-study, A Åsberg, AV Reisæter, A Bjerre, A Zurowska, I Zagozdzon, C Mota, R Stone, G Mirescu, L Garneata, M Kostić, B Spasojević, M Cvetković, I Gojković, D Paripović, G MiloševskiLomić, EA Molchanova, EV Zakharova, AM Andrusev, KG Prütz, M Stendahl, M Evans, S Schön, M Segelmark, T Lundgren, L Podracka, G Kolvek, N Battelino, G Novljan, J Buturovic-Ponikvar, S Bakkaloglu, DD Ivanov, SP Fomina, L Plumb, F Braddon, A Casula, MD Sinha, H Maxwell, and SD Marks for contributing data to the ESPN/ERA-EDTA Registry.

Funding The ESPN/ERA-EDTA Registry is funded by the European Society of Paediatric Nephrology (ESPN), and the European Renal Association-European Dialysis and Transplant Association (ERAEDTA). Furthermore, Amgen has agreed to provide an unrestricted grant to assist the ERA-EDTA on the financial support of the ESPN/ERAEDTA Registry.

\section{Declarations}

Conflict of interest The authors declare no competing interests.
Open Access This article is licensed under a Creative Commons Attribution 4.0 International License, which permits use, sharing, adaptation, distribution and reproduction in any medium or format, as long as you give appropriate credit to the original author(s) and the source, provide a link to the Creative Commons licence, and indicate if changes were made. The images or other third party material in this article are included in the article's Creative Commons licence, unless indicated otherwise in a credit line to the material. If material is not included in the article's Creative Commons licence and your intended use is not permitted by statutory regulation or exceeds the permitted use, you will need to obtain permission directly from the copyright holder. To view a copy of this licence, visit http://creativecommons.org/licenses/by/4.0/.

\section{References}

1. Janjua HS, Mahan JD (2011) Growth in chronic kidney disease. Adv Chronic Kidney Dis 18:324-331

2. Seikaly MG, Salhab N, Gipson D, Yiu V, Stablein D (2006) Stature in children with chronic kidney disease: analysis of NAPRTCS database. Pediatr Nephrol 21:793-799

3. Feld S, Hirschberg R (1996) Growth hormone, the insulin-like growth factor system, and the kidney. Endocr Rev 17:423-480

4. Drube J, Wan M, Bonthuis M, Wühl E, Bacchetta J, Santos F, Grenda R, Edefonti A, Harambat J, Shroff R, Tönshoff B, Haffner D, European Society for Paediatric Nephrology Chronic Kidney Disease Mineral and Bone Disorders, Dialysis, and Transplantation Working Groups (2019) Clinical practice recommendations for growth hormone treatment in children with chronic kidney disease. Nat Rev Nephrol 15:577-589

5. Furth SL, Stablein D, Fine RN, Powe NR, Fivush BA (2002) Adverse clinical outcomes associated with short stature at dialysis initiation: a report of the North American Pediatric Renal Transplant Cooperative Study. Pediatrics 109:909-913

6. Harambat J, Bonthuis M, van Stralen KJ, Ariceta G, Battelino N, Bjerre A, Jahnukainen T, Leroy V, Reusz G, Sandes AR, Sinha MD, Groothoff JW, Combe C, Jager KJ, Verrina E, Schaefer F (2014) Adult height in patients with advanced $\mathrm{CKD}$ requiring renal replacement therapy during childhood. Clin J Am Soc Nephrol 9:92-99

7. Furth SL, Hwang W, Yang C, Neu AM, Fivush BA, Powe NR (2002) Growth failure, risk of hospitalization and death for children with end-stage renal disease. Pediatr Nephrol 17:450-455

8. Nawrot-Wawrzyniak K, Misof BM, Roschger P, PańczykTomaszewska M, Ziółkowska H, Klaushofer K, Fratzl-Zelman N (2013) Changes in bone matrix mineralization after growth hormone treatment in children and adolescents with chronic kidney failure treated by dialysis: a paired biopsy study. Am J Kidney Dis 61:767-777

9. Ku E, Fine RN, Hsu CY, McCulloch C, Glidden DV, Grimes B, Johansen KL (2016) Height at first RRT and mortality in children. Clin J Am Soc Nephrol 11:832-839

10. Reynolds JM, Wood AJ, Eminson DM, Postlethwaite RJ (1995) Short stature and chronic renal failure: what concerns children and parents? Arch Dis Child 73:36-42

11. Al-Uzri A, Matheson M, Gipson DS, Mendley SR, Hooper SR, Yadin O, Rozansky DJ, Moxey-Mims M, Furth SL, Warady BA, Gerson AC, Chronic Kidney Disease in Children Study Group (2013) The impact of short stature on health-related quality of life in children with chronic kidney disease. J Pediatr 163:736-741 el

12. Broyer M, Le Bihan C, Charbit M, Guest G, Tete MJ, Gagnadoux MF, Niaudet P (2004) Long-term social outcome of children after kidney transplantation. Transplantation 77:1033-1037 
13. Harmer M, Wootton S, Gilbert R, Anderson C (2019) Association of nutritional status and health-related quality of life in children with chronic kidney disease. Qual Life Res 28:1565-1573

14. Francis A, Didsbury MS, van Zwieten A, Chen K, James LJ, Kim S, Howard K, Williams G, Bahat Treidel O, McTaggart S, Walker A, Mackie F, Kara T, Nassar N, Teixeira-Pinto A, Tong A, Johnson D, Craig JC, Wong G (2019) Quality of life of children and adolescents with chronic kidney disease: a cross-sectional study. Arch Dis Child 104:134-140

15. Stabler B, Clopper RR, Siegel PT, Stoppani C, Compton PG, Underwood LE (1994) Academic achievement and psychological adjustment in short children. The National Cooperative Growth Study. J Dev Behav Pediatr 15:1-6

16. Kang NR, Ahn YH, Park E, Choi HJ, Kim SH, Cho H, Cho MH, Shin JI, Lee JH, Park YS, Cheong HI, Kang HG, Ha IS, Kwack YS, Han KH (2019) Mental health and psychosocial adjustment in pediatric chronic kidney disease derived from the KNOW-Ped CKD study. Pediatr Nephrol 34:1753-1764

17. Rosenkranz J, Reichwald-Klugger E, Oh J, Turzer M, Mehls O, Schaefer F (2005) Psychosocial rehabilitation and satisfaction with life in adults with childhood-onset of end-stage renal disease. Pediatr Nephrol 20:1288-1294

18. Tjaden LA, Vogelzang J, Jager KJ, van Stralen KJ, Maurice-Stam H, Grootenhuis MA, Groothoff JW (2014) Long-term quality of life and social outcome of childhood end-stage renal disease. J Pediatr 165:336$342 \mathrm{e} 1$

19. Mellerio H, Alberti C, Labèguerie M, Andriss B, Savoye E, Lassalle M, Jacquelinet C, Loirat C, French Working Group on the Long-Term Outcome of Transplanted Children (2014) Adult social and professional outcomes of pediatric renal transplant recipients. Transplantation 97:196-205

20. Li Y, Greenbaum LA, Warady BA, Furth SL, Ng DK (2019) Short stature in advanced pediatric CKD is associated with faster time to reduced kidney function after transplant. Pediatr Nephrol 34:897-905

21. Wong CS, Gipson DS, Gillen DL, Emerson S, Koepsell T, Sherrard DJ, Watkins SL, Stehman-Breen C (2000) Anthropometric measures and risk of death in children with end-stage renal disease. Am J Kidney Dis 36:811-819

22. Fine RN, Ho M, Tejani A, North American Pediatric Renal Trasplant Cooperative Study (NAPRTCS) (2001) The contribution of renal transplantation to final adult height: a report of the North American Pediatric Renal Transplant Cooperative Study (NAPRTCS). Pediatr Nephrol 16:951-956

23. Franke D, Winkel S, Gellermann J, Querfeld U, Pape L, Ehrich JH et al (2013) Growth and maturation improvement in children on renal replacement therapy over the past 20 years. Pediatr Nephrol 28:2043-2051

24. North American Pediatric Renal Trials and Collaborative Studies (2014) NAPRTCS 2014 Annual Report. EMMES Corporation, Rockville

25. Bonthuis M, Groothoff JW, Ariceta G, Baiko S, Battelino N, Bjerre A, Cransberg K, Kolvek G, Maxwell H, Miteva P, Molchanova MS, Neuhaus TJ, Pape L, Reusz G, Rousset-Rouviere C, Sandes AR, Topaloglu R, Van Dyck M, Ylinen E, Zagozdzon I, Jager KJ, Harambat J (2020) Growth patterns after kidney transplantation in European children over the past 25 years: an ESPN/ERA-EDTA Registry Study. Transplantation 104:137-144

26. North American Pediatric Renal Trials and Collaborative Studies (2011) 2011 Annual Dialysis Report. EMMES Corporation, Rockville

27. Chadha V, Blowey DL, Warady BA (2001) Is growth a valid outcome measure of dialysis clearance in children undergoing peritoneal dialysis? Perit Dial Int 21(Suppl 3):S179-S184

28. Borzych D, Rees L, Ha IS, Chua A, Valles PG, Lipka M et al (2010) The bone and mineral disorder of children undergoing chronic peritoneal dialysis. Kidney Int 78:1295-1304

29. Ledermann SE, Scanes ME, Fernando ON, Duffy PG, Madden SJ, Trompeter RS (2000) Long-term outcome of peritoneal dialysis in infants. J Pediatr 136:24-29
30. Vidal E, Edefonti A, Murer L, Gianoglio B, Maringhini S, Pecoraro C, Sorino P, Leozappa G, Lavoratti G, Ratsch IM, Chimenz R, Verrina E, Italian Registry of Paediatric Chronic Dialysis (2012) Peritoneal dialysis in infants: the experience of the Italian Registry of Paediatric Chronic Dialysis. Nephrol Dial Transplant 27:388395

31. Rees L, Azocar M, Borzych D, Watson AR, Büscher A, Edefonti A, Bilge I, Askenazi D, Leozappa G, Gonzales C, van Hoeck K, Secker D, Zurowska A, Rönnholm K, Bouts AH, Stewart H, Ariceta G, Ranchin B, Warady BA, Schaefer F, International Pediatric Peritoneal Dialysis Network (IPPN) registry (2011) Growth in very young children undergoing chronic peritoneal dialysis. J Am Soc Nephrol 22:2303-2312

32. Fischbach M, Terzic J, Laugel V, Dheu C, Menouer S, Helms P et al (2004) Daily on-line haemodiafiltration: a pilot trial in children. Nephrol Dial Transplant 19:2360-2367

33. de Camargo MF, Henriques CL, Vieira S, Komi S, Leão ER, Nogueira PC (2014) Growth of children with end-stage renal disease undergoing daily hemodialysis. Pediatr Nephrol 29:439-444

34. Shroff R, Smith C, Ranchin B, Bayazit AK, Stefanidis CJ, Askiti V et al (2019) Effects of hemodiafiltration versus conventional hemodialysis in children with ESKD: the HDF, Heart and Height Study. J Am Soc Nephrol 30:678-691

35. Schaefer F, Wingen AM, Hennicke M, Rigden S, Mehls O (1996) Growth charts for prepubertal children with chronic renal failure due to congenital renal disorders. European Study Group for Nutritional Treatment of Chronic Renal Failure in Childhood. Pediatr Nephrol 10:288-293

36. North American Pediatric Renal Trials and Collaborative Studies (2006) NAPRTCS 2006 Annual Transplant Report. EMMES Corporation, Rockville

37. Mekahli D, Shaw V, Ledermann SE, Rees L (2010) Long-term outcome of infants with severe chronic kidney disease. Clin J Am Soc Nephrol 5:10-17

38. Fine RN, Martz K, Stablein D (2010) What have 20 years of data from the North American Pediatric Renal Transplant Cooperative Study taught us about growth following renal transplantation in infants, children, and adolescents with end-stage renal disease? Pediatr Nephrol 25:739-746

39. Nissel R, Brázda I, Feneberg R, Wigger M, Greiner C, Querfeld U, Haffner D (2004) Effect of renal transplantation in childhood on longitudinal growth and adult height. Kidney Int 66:792-800

40. Hokken-Koelega AC, van Zaal MA, van Bergen W, de Ridder MA, Stijnen T, Wolff ED et al (1994) Final height and its predictive factors after renal transplantation in childhood. Pediatr Res 36:323-328

41. Haffner D, Zivicnjak M (2017) Pubertal development in children with chronic kidney disease. Pediatr Nephrol 32:949-964

42. Tainio J, Qvist E, Vehmas R, Jahnukainen K, Holtta T, Valta H et al (2011) Pubertal development is normal in adolescents after renal transplantation in childhood. Transplantation 92:404-409

43. Maxwell H, Haffner D, Rees L (1998) Catch-up growth occurs after renal transplantation in children of pubertal age. J Pediatr 133:435-440

44. Pennisi AJ, Costin G, Phillips LS, Uittenbogaart C, Ettenger RB, Malekzadeh MH et al (1977) Linear growth in long-term renal allograft recipients. Clin Nephrol 8:415-421

45. Guest G, Broyer M (1991) Growth after renal transplantation: correlation with immunosuppressive therapy. Pediatr Nephrol 5:143-146

46. Grohs J, Rebling RM, Froede K, Hmeidi K, Pavičić L, Gellermann J, Müller D, Querfeld U, Haffner D, Živičnjak M (2021) Determinants of growth after kidney transplantation in prepubertal children. Pediatr Nephrol. https://doi.org/10.1007/s00467-02104922-2

47. Blodgett FM, Burgin L, Iezzoni D, Gribetz D, Talbot NB (1956) Effects of prolonged cortisone therapy on the statural growth, skeletal maturation and metabolic status of children. N Engl J Med 254:636-641 
48. Delucchi Á, Toro L, Alzamora R, Barrientos V, González M, Andaur R, León P, Villanueva F, Galindo M, Las Heras F, Montecino M, Moena D, Lazcano A, Pinto V, Salas P, Reyes ML, Mericq V, Michea L (2019) Glucocorticoids decrease longitudinal bone growth in pediatric kidney transplant recipients by stimulating the FGF23/ FGFR3 signaling pathway. J Bone Miner Res 34:1851-1861

49. Sarna S, Hoppu K, Neuvonen PJ, Laine J, Holmberg C (1997) Methylprednisolone exposure, rather than dose, predicts adrenal suppression and growth inhibition in children with liver and renal transplants. J Clin Endocrinol Metab 82:75-77

50. Seikku P, Raivio T, Janne OA, Neuvonen PJ, Holmberg C (2006) Methylprednisolone exposure in pediatric renal transplant patients. Am J Transplant 6:1451-1458

51. Chavatte C, Guest G, Proust V, Le Bihan C, Gimenez F, Maisin A, Loirat C, Mogenet A, Bresson JL, Hankard R, Broyer M, Niaudet P, Singlas E (2004) Glucocorticoid pharmacokinetics and growth retardation in children with renal transplants. Pediatr Nephrol 19: 898-904

52. Franke D, Thomas L, Steffens R, Pavičić L, Gellermann J, Froede K, Querfeld U, Haffner D, Živičnjak M (2015) Patterns of growth after kidney transplantation among children with ESRD. Clin J Am Soc Nephrol 10:127-134

53. Broyer M, Guest G, Gagnadoux MF (1992) Growth rate in children receiving alternate-day corticosteroid treatment after kidney transplantation. J Pediatr 120:721-725

54. Jabs K, Sullivan EK, Avner ED, Harmon WE (1996) Alternate-day steroid dosing improves growth without adversely affecting graft survival or long-term graft function. A report of the North American Pediatric Renal Transplant Cooperative Study. Transplantation 61:3136

55. Höcker B, Weber LT, Feneberg R, Drube J, John U, Fehrenbach H, Pohl M, Zimmering M, Fründ S, Klaus G, Wühl E, Tönshoff B (2010) Improved growth and cardiovascular risk after late steroid withdrawal: 2-year results of a prospective, randomised trial in paediatric renal transplantation. Nephrol Dial Transplant 25:617-624

56. Benfield MR, Bartosh S, Ikle D, Warshaw B, Bridges N, Morrison Y, Harmon W (2010) A randomized double-blind, placebo controlled trial of steroid withdrawal after pediatric renal transplantation. Am J Transplant 10:81-88

57. Sarwal MM, Ettenger RB, Dharnidharka V, Benfield M, Mathias R, Portale A, McDonald R, Harmon W, Kershaw D, Vehaskari VM, Kamil E, Baluarte HJ, Warady B, Tang L, Liu J, Li L, Naesens M, Sigdel T, Waskerwitz J, Salvatierra O (2012) Complete steroid avoidance is effective and safe in children with renal transplants: a multicenter randomized trial with three-year follow-up. Am J Transplant 12:2719-2729

58. Mericq V, Salas P, Pinto V, Cano F, Reyes L, Brown K, Gonzalez M, Michea L, Delgado I, Delucchi A (2013) Steroid withdrawal in pediatric kidney transplant allows better growth, lipids and body composition: a randomized controlled trial. Horm Res Paediatr 79: 88-96

59. Webb NJ, Douglas SE, Rajai A, Roberts SA, Grenda R, Marks SD, Watson AR, Fitzpatrick M, Vondrak K, Maxwell H, Jaray J, Van Damme-Lombaerts R, Milford DV, Godefroid N, Cochat P, Ognjanovic M, Murer L, McCulloch M, Tönshoff B (2015) Corticosteroid-free kidney transplantation improves growth: 2year follow-up of the TWIST randomized controlled trial. Transplantation 99:1178-1185

60. Pape L, Ehrich JH, Zivicnjak M, Offner G (2005) Growth in children after kidney transplantation with living related donor graft or cadaveric graft. Lancet 366:151-153

61. Englund MS, Tyden G, Wikstad I, Berg UB (2003) Growth impairment at renal transplantation - a determinant of growth and final height. Pediatr Transplant 7:192-199

62. Tejani A, Cortes L, Sullivan EK (1996) longitudinal study of the natural history of growth post-transplantation. Kidney Int Suppl 53:103-108
63. Franke D, Steffens R, Thomas L, Pavičić L, Ahlenstiel T, Pape L, Gellermann J, Müller D, Querfeld U, Haffner D, Živičnjak M (2017) Kidney transplantation fails to provide adequate growth in children with chronic kidney disease born small for gestational age. Pediatr Nephrol 32:511-519

64. Shroff R, Knott C, Gullett A, Wells D, Marks SD, Rees L (2011) Vitamin D deficiency is associated with short stature and may influence blood pressure control in paediatric renal transplant recipients. Pediatr Nephrol 26:2227-2233

65. Klare B, Montoya CR, Fischer DC, Stangl MJ, Haffner D (2012) Normal adult height after steroid-withdrawal within 6 months of pediatric kidney transplantation: a 20 years single center experience. Transpl Int 25:276-282

66. Hasegawa A, Motoyama O, Shishido S, Ito K, Tsuzuki K, Takahashi K et al (2004) A prospective trial of steroid withdrawal after renal transplantation in children: results obtained 1990 and 2002. Transplant Proc 36(2 Suppl):216S-219S

67. Gil S, Aziz M, Adragna M, Monteverde M, Belgorosky A (2018) Nearadult height in male kidney transplant recipients started on growth hormone treatment in late puberty. Pediatr Nephrol 33:175-180

68. Hasegawa A, Motoyama O, Shishido S, Ito K, Tsuzuki K, Takahashi K, Ohshima S (2012) Use of national and international growth charts for studying height in European children: development of up-to-date European height-for-age charts. PLoS One 7:e42506

69. Jung HW, Kim HY, Lee YA, Kang HG, Shin CH, Ha IS, Cheong HI, Yang SW. (2013) Factors affecting growth and final adult height after pediatric renal transplantation. Transplant Proc 45: $108-114$

70. Nissel R, Lindberg A, Mehls O, Haffner D, Pfizer International Growth Database (KIGS) International Board (2008) Factors predicting the near-final height in growth hormone-treated children and adolescents with chronic kidney disease. J Clin Endocrinol Metab 93:1359-1365

71. Gil S, Vaiani E, Guercio G, Ciaccio M, Turconi A, Delgado N, Rivarola MA, Belgorosky A (2012) Effectiveness of rhGH treatment on final height of renal-transplant recipients in childhood. Pediatr Nephrol 27:1005-1009

72. van Huis M, Bonthuis M, Sahpazova E, Mencarelli F, Spasojević B, Reusz G, Caldas-Afonso A, Bjerre A, Baiko S, Vondrak K, Molchanova EA, Kolvek G, Zaikova N, Böhm M, Ariceta G, Jager KJ, Schaefer F, van Stralen KJ, Groothoff JW (2016) Considerable variations in growth hormone policy and prescription in paediatric end-stage renal disease across European countries - a report from the ESPN/ERA-EDTA registry. Nephrol Dial Transplant 31:609-619

73. Rees L, Mak RH (2011) Nutrition and growth in children with chronic kidney disease. Nat Rev Nephrol 7:615-623

74. Armstrong JE, Laing DG, Wilkes FJ, Kainer G (2010) Smell and taste function in children with chronic kidney disease. Pediatr Nephrol 25:1497-1504

75. Ingulli EG, Mak RH (2014) Growth in children with chronic kidney disease: role of nutrition, growth hormone, dialysis, and steroids. Curr Opin Pediatr 26:187-192

76. Mak RH, Cheung W, Cone RD, Marks DL (2006) Leptin and inflammation-associated cachexia in chronic kidney disease. Kidney Int 69:794-797

77. Norman LJ, Coleman JE, Macdonald IA, Tomsett AM, Watson AR (2000) Nutrition and growth in relation to severity of renal disease in children. Pediatr Nephrol 15:259-265

78. Shaw V, Polderman N, Renken-Terhaerdt J, Paglialonga F, Oosterveld M, Tuokkola J, Anderson C, Desloovere A, Greenbaum L, Haffner D, Nelms C, Qizalbash L, Vande Walle J, Warady B, Shroff R, Rees L (2020) Energy and protein requirements for children with CKD stages 2-5 and on dialysis-clinical practice recommendations from the Pediatric Renal Nutrition Taskforce. Pediatr Nephrol 35:519-531 
79. Marlais M, Stojanovic J, Jones H, Cleghorn S, Rees L (2020) Catch-up growth in children with chronic kidney disease started on enteral feeding after 2 years of age. Pediatr Nephrol 35:113-118

80. Schaefer F, Benner L, Borzych-Dużałka D, Zaritsky J, Xu H, Rees L, Antonio ZL, Serdaroglu E, Hooman N, Patel H, Sever L, Vondrak K, Flynn J, Rébori A, Wong W, Hölttä T, Yildirim ZY, Ranchin B, Grenda R, Testa S, Drożdz D, Szabo AJ, Eid L, Basu B, Vitkevic R, Wong C, Pottoore SJ, Müller D, Dusunsel R, Celedon CG, Fila M, Sartz L, Sander A, Warady BA, International Pediatric Peritoneal Dialysis Network (IPPN) Registry (2019) Global variation of nutritional status in children undergoing chronic peritoneal dialysis: a longitudinal study of the International Pediatric Peritoneal Dialysis Network. Sci Rep 9:4886

81. Bonthuis M, van Stralen KJ, Verrina E, Groothoff JW, Alonso Melgar Á, Edefonti A, Fischbach M, Mendes P, Molchanova EA, Paripović D, Peco-Antic A, Printza N, Rees L, Rubik J, Stefanidis CJ, Sinha MD, Zagożdżon I, Jager KJ, Schaefer F (2013) Underweight, overweight and obesity in paediatric dialysis and renal transplant patients. Nephrol Dial Transplant 28(Suppl 4): iv195-iv204

82. Hanevold CD, Ho PL, Talley L, Mitsnefes MM (2005) Obesity and renal transplant outcome: a report of the North American Pediatric Renal Transplant Cooperative Study. Pediatrics 115:352-356

83. Hui WF, Betoko A, Savant JD, Abraham AG, Greenbaum LA, Warady B, Moxey-Mims MM, Furth SL (2017) Assessment of dietary intake of children with chronic kidney disease. Pediatr Nephrol 32:485-494
84. Chen W, Ducharme-Smith K, Davis L, Hui WF, Warady BA, Furth SL, Abraham AG, Betoko A (2017) Dietary sources of energy and nutrient intake among children and adolescents with chronic kidney disease. Pediatr Nephrol 32:1233-1241

85. Coleman JE, Norman LJ, Watson AR (1999) Provision of dietetic care in children on chronic peritoneal dialysis. J Ren Nutr 9:145-148

86. National Kidney Foundation (2009) KDOQI clinical practice guideline for nutrition in children with CKD: 2008 update. Executive summary. Am J Kidney Dis 53(3 Suppl 2):S11-S104

87. Hodson EM, Willis NS, Craig JC (2012) Growth hormone for children with chronic kidney disease. Cochrane Database Syst Rev 2:CD003264

88. Seikaly MG, Waber P, Warady BA, Stablein D (2009) The effect of rhGH on height velocity and BMI in children with CKD: a report of the NAPRTCS registry. Pediatr Nephrol 24:1711-1717

89. Hokken-Koelega A, Mulder P, De Jong R, Lilien M, Donckerwolcke R, Groothof J (2000) Long-term effects of growth hormone treatment on growth and puberty in patients with chronic renal insufficiency. Pediatr Nephrol 14:701-706

Answers: 1. a; 2. d; 3. d; 4. b; 5. d

Publisher's note Springer Nature remains neutral with regard to jurisdictional claims in published maps and institutional affiliations. 